\title{
Profile of Serum Metabolites and Proteins of Broiler Breeders in Rearing Age
}

\section{-Author(s)}

\section{Rezende MS \\ Mundim AV" \\ Fonseca BB"II \\ Miranda RL IV \\ Oliveira Jr W \\ Lellis CGV}

PhD student of the Post-Graduation Program in Veterinary Science of the Federal University of Uberlândia

" PhD Professor at the Post-Graduation Program in Veterinary Science of the Federal University of Uberlândia

III PhD Professor, School of Veterinary Medicine, Federal University of Uberlândia

Iv MDV, PhD - Veterinary Hospital Clinical Laboratory, School of Veterinary Medicine, Federal University of Uberlandia

$\checkmark$ MDV, resident at the Veterinary Hospital, School of Veterinary Medicine, Federal University of Uberlandia

VI MDV, graduate student at SPEI

\section{ABSTRACT}

The excellence of modern broiler production is based on the genetic improvement of broiler strains for high growth rate and high egg production, associated with technological developments in nutrition, management, and health. Over the last decades, the clinical biochemistry of broilers has been studied to determine serum biochemical component values; however, there are still many knowledge gaps on factors that determine changes in these values. In this study, the serum lipid and protein profiles of 4-week-old male and female Cobb broiler breeders were evaluated. Blood samples were collected on a commercial farm located in the city of Uberlândia, MG, Brazil. The following parameters were evaluated: total protein, albumin, globulin, albumin to globulin ratio (ANV), uric acid, urea, cholesterol, and triglyceride levels using an automatic analyzer. The results showed sex-specific biochemical patterns for most blood parameters evaluated. Moreover, the obtained values were different from those obtained in many published studies with broilers and commercial layers, stressing the need to develop further studies with chickens of different ages.

\section{INTRODUCTION}

The Brazilian poultry industry has significantly developed in recent years, and today is one of the most important economic activities in that country. Its outstanding productivity is based on recent progresses in poultry production, which is today characterized by high competitiveness and advanced technological standards (Silva, 2000).

In order to maximize the production potential of poultry, body functions need to be in perfect balance, known as homeostasis. In this context, the knowledge of the levels of some blood parameters provides important information to determine body balance status, reflecting the requirements of metabolic processes.

Blood biochemical analysis is widely used to assist the diagnosis and characterization of diseases in most animal species, but it is seldom used in avian species. However, it is an important tool, as some metabolic disorders are difficult to detect only by clinical signs (Andreasen et al., 1996). It can also assist the monitoring of poultry health, the diagnosis and treatment of diseases, and to assess their health status (Schmidt et al., 2007).

The aim of this study was to determine the profile of serum proteins, lipids, and metabolites of Cobb broiler breeders, so that it could be used as a benchmark for a comparative analysis between males and females in a commercial breeding system, at the age of four weeks. 
Rezende MS, Mundim AV, Fonseca BB, Miranda RL, Oliveira Jr W, Lellis CG
Profile of Serum Metabolites and Proteins of Broiler Breeders in Rearing Age

\section{MATERIAL AND METHODS}

\section{Birds, management, and diets}

All the procedures applied in this study were conducted in accordance with the standards of the Ethics Committee on the Use of Animals of the Federal University of Uberlândia, and approved under protocol CEUA/UFU 004/16.

The study was conducted on a commercial broiler breeder farm, located in Uberlândia, state of Minas Gerais, Brazil, in April of 2016.

In total, 13,500 female and 1,755 day-old male Cobb breeders were housed in a $2800-\mathrm{m}^{2}$ house. The house was equipped with nipple drinkers, automatic trough feeders, air conditioning system with exhaustion fans, and evaporative cooling pads. During the first three days, a photoperiod of $23 \mathrm{~h}$ of light was applied, after which it was gradually decreased and stabilized at $9 \mathrm{~h}$ of light from the third week on. The light intensity was 4 lux, and controlled by black/silver curtains.

During the four first weeks of age, the broilers were fed a starter diet based on corn and soybean meal, containing 20.5\% crude protein and 2950 $\mathrm{kcal}$ metabolizable energy/kg. Feed intake was daily monitored for body weight control.

\section{Blood sampling and weight of broilers}

At 28 days of age, 15 birds of each gender were individually weighed on digital scale (1g accuracy), and then blood samples were collected by puncture of the ulnar vein, using sterile syringes and needles after $6 \mathrm{~h}$ of fasting. An aliquot of $3 \mathrm{~mL}$ of blood was collected and transferred to sterile tubes without anticoagulant. The collected blood samples were submitted in insulated boxes to the Clinical Laboratory of the Veterinary Hospital of the Federal University of Uberlândia. Upon arrival, samples were centrifuged at $720 \times \mathrm{xg}$ for 10 minutes. The obtained sera were transferred to microtubes and stored under refrigeration $\left(2^{\circ}\right.$ to $\left.8^{\circ} \mathrm{C}\right)$ for 24 hours until serum biochemical analyses.

Levels of total protein (biuret method), albumin (bromocresol green method), globulins (calculated as the difference between the total protein and albumin), uric acid (Trinder enzymatic method), urea (ultraviolet kinetic enzymatic method), total cholesterol, and triglyrecides (Trinder enzymatic method) were determined in individual samples in an automatic analyzer (Chemwell ${ }^{\circledR}$, Megazyme, Wicklow, Ireland), and using commercial kits (Labtest Diagnóstica S.A, Lagoa Santa, Brazil). The automatic analyzer was previously calibrated with caliber 1 and measured with the control serum Qualitrol 1H, both manufactured by Labtest Diagnóstica ${ }^{\circledR}$.

\section{Statistical Analysis}

Data were analyzed according to a completely randomized design, with 15 sampling units per gender to evaluate the effect of the gender of 4-week-old broilers on blood chemical profile.

Data normality was tested by the KolmogorovSmirnov test at 5\% significance levels, which showed that presented normal distribution. Data were submitted to analysis of variance, and the test of Tukey was applied to determine possible difference between genders, at 5\% significance levels. The software GraphPad Prism 5.1 was used for statistical analyses.

\section{RESULTS}

\section{Body weight}

Average body weights of $538.33 \pm 14.10 \mathrm{~g}$ and $686.80 \pm 23.16 \mathrm{~g}$ were determined for females and males, respectively, and were statistically different $(p<0.05)$ (Table 1).

Table 1 - Mean and standard deviation values of the body weight and serum biochemical parameters of 4-week-old female and male broiler breeders.

\begin{tabular}{lcc}
\hline Parameter & Females & Males \\
\hline Body weight $(\mathrm{g})$ & $538.33 \mathrm{a} \pm 14,10$ & $686.80 \mathrm{~b} \pm 23.16$ \\
\hline Total protein $(\mathrm{g} / \mathrm{L})$ & $28.00 \mathrm{~b} \pm 4.30$ & $24.60 \mathrm{a} \pm 4.20$ \\
Albumin $(\mathrm{g} / \mathrm{L})$ & $13.70 \mathrm{~b} \pm 1.90$ & $10.60 \mathrm{a} \pm 1.90$ \\
Globulins $(\mathrm{g} / \mathrm{L})$ & $14.30 \pm 2.60$ & $14.00 \pm 2.80$ \\
A/G ratio & $0.97 \mathrm{~b} \pm 0.11$ & $0.77 \mathrm{a} \pm 0.13$ \\
Uric acid $(\mathrm{mmol} / \mathrm{L})$ & $3.71 \mathrm{a} \pm 1.50$ & $5.03 \mathrm{~b} \pm 1.40$ \\
Urea $(\mathrm{mmol} / \mathrm{L})$ & $6.50 \pm 2.21$ & $7.34 \pm 3.75$ \\
\hline Cholesterol $(\mathrm{mmol} / \mathrm{L})$ & $3.44 \mathrm{~b} \pm 0.53$ & $2.80 \mathrm{a} \pm 0.43$ \\
Triglycerides $(\mathrm{mmol} / \mathrm{L})$ & $0.57 \mathrm{a} \pm 0.21$ & $1.25 \mathrm{~b} \pm 0.22$ \\
\hline
\end{tabular}

$\mathrm{A} / \mathrm{G}$ ratio $=$ Albumin $/$ Globulin ratio

Mean followed by different letters in the same row differ by the Tukey test $(p<0.05)$.

\section{Serum biochemical parameters}

Comparing the serum biochemical parameters between males and females, it was observed that females presented significantly higher serum concentrations of total protein, albumin, AVG ratio, cholesterol, uric acid, and triglycerides than males $(p<0.05)$, while the serum concentrations of globulin and urea were similar ( $p>0.05)$ for males and females (Table 1). 
Rezende MS, Mundim AV, Fonseca BB, Miranda RL, Oliveira Jr W, Lellis CG
Profile of Serum Metabolites and Proteins of Broiler Breeders in Rearing Age

\section{DISCUSSION}

\section{Body weight}

The genetic improvement of broilers for fast growth, high-meat yield, and good feed conversion ratio entails the selection of broiler breeders with these characteristics. However, when broiler breeders are fed ad libitum, they present excessive body weight and fat accumulation, which compromises their productive and reproductive performance. Therefore, it is essential to control their body weight, mainly during the rearing period, to allow them to achieve sexual maturity with adequate body weight and at the desired age (Vieira et al., 1995).

The body weight recommended by the genetic company (Cobb, 2013) for 4-week-old breeders of the evaluated strain is $540 \mathrm{~g}$ for females and $690 \mathrm{~g}$ for males. In the present study, body weights of $538.33 \mathrm{~g}$ and $686.80 \mathrm{~g}$ were determined in females and males, respectively, corresponding to variations of $-0.31 \%$ and $-0.46 \%$ from the recommended values, respectively. These values are very close to those recommended for this strain, and therefore, indicate that the body development of the evaluated birds complied with the recommended standard.

\section{Serum biochemical parameters}

There are few studies available in literature (Schmidt et al., 2007) on the blood biochemical profile of poultry.

Serum proteins are mainly synthesized in the liver, and, among other functions, maintain blood volume through the colloidal osmotic effect, buffer blood $\mathrm{pH}$, transport hormones and drugs, participate in cell coagulation, catalyze chemical reactions (enzymes), regulate the metabolism (hormones), and participate in the body defense against foreign agents (Melillo, 2013).

The higher total protein concentration determined in the serum of females compared with males is attributed to their higher albumin values, as globulin values were statistically similar (Table 1). According to Harr et al. (2002), serum total protein values of broilers tend to be lower than those of mammals, ranging from 25.00 to $45.00 \mathrm{~g} / \mathrm{L}$.

Albumin values were higher in females than in males (Table 1), although males consumed a greater amount of feed and protein. Using the same diet, with intake of grams/broiler/day higher by males, the difference in values may suggest a higher protein intake by them, in order to meet the demand for higher body development. Ross et al. (1978) determined albumin values of $10.80-16.10 \mathrm{~g} / \mathrm{L}$ in broilers, whereas Barbosa et al. (2011) found 11.40-12.10 g/L in commercial layers during lay. The main functions of albumin are the transport of several molecules and the maintenance of blood oncotic pressure (Melillo, 2013).

The similar globulin values determined in males and females suggest that both genders presented the same health status at the age studied. Kudair \& Al-Hussary (2010) showed increased globulin levels of in broilers submitted to vaccination (against infectious bronchitis, Newcastle disease and infectious bursal disease), with values ranging between 10.00-11.90 g/L in nonvaccinated birds and $16.30-19.20 \mathrm{~g} / \mathrm{L}$ in the vaccinated ones.

The $A / G$ ratio values of females were higher than those of males due to the higher albumin concentration in females. When this ratio is reduced, there may be hypoproteinemia, and may indicate acute or chronic inflammatory processes due to the elevation of globulins (Lumeij, 1997).

Higher uric acid values were determined in males than in females. Uric acid is the main product of protein nitrogen and purine metabolism in poultry. Approximately $90 \%$ of the uric acid is secreted by the proximal convoluted tubules in healthy broilers (Harr, 2002). The highest values found in males may reflect their protein metabolism rate at this age, as they have a higher body growth rate than females. According to Benez (2004), the values found in broilers ranged between 0.12 and $0.89 \mathrm{mmol} / \mathrm{L}$. Ross et al. (1978) obtained an average serum uric acid levels of 0.46 $\mathrm{mmol} / \mathrm{L}$ in broilers. Serum uric acid levels are influenced by the diet, hydration status, and species (Lumeij, 2008).

Serum urea levels were not influenced by gender. The urea values determined in the present study are consistent with those found by Batina et al. (2005) for broilers, ranging between 6.5 and $7.76 \mathrm{mg} / \mathrm{dL}$.

Serum cholesterol levels were higher in females than in males. According to Peebles et al. (2004), the levels of LDL and VLDL, which are lipoproteins associated with the transport of cholesterol, are much lower in males than in females, compared to HDL levels, responsible for the reduction of serum cholesterol. Cholesterol levels can also be influenced by age, diet, and reproductive activity (Harr, 2002; Alonso-Alvarez, 2005). Ross et al. (1978) reported cholesterol values of $1.86-3.37 \mathrm{mmol} / \mathrm{L}$ in broilers.

Triglycerides are synthesized in the intestinal mucosa and in the liver from the digestion of dietary components and the absorption of fatty acids. Serum 
Rezende MS, Mundim AV,

Fonseca BB, Miranda RL,

Oliveira Jr W, Lellis CG
Profile of Serum Metabolites and Proteins of Broiler

Breeders in Rearing Age triglyceride levels of poultry are influenced by sex, diet, and hormonal factors (Hochleithner, 1994). In the present study, the triglyceride levels of males were higher compared to females. On the other hand, Musa et al. (2007), in a study with 12-week-old chickens of the Anka and Rugao breeds, did not find significantly different levels of triglycerides between males e females. In the study of Evans et al. (1977), the serum triglyceride values in broilers ranged between 1.54 and $1.88 \mathrm{mmol} / \mathrm{L}$, when a diet with around 3,000 kcal metabolizable energy/kg was fed. Comparing serum triglycerides levels between two commercial strains of broilers at 36 days of age reared under the same conditions, Osorio et al. (2012) obtained values of 0.28 $\mathrm{mmol} / \mathrm{L}$ and $0.23 \mathrm{mmol} / \mathrm{L}$, with a feed containing $18 \%$ crude protein and $3150 \mathrm{kcal}$ metabolizable energy/kg.

\section{CONCLUSIONS}

The body weight of the broiler breeders evaluated in this study was within the recommended weight range for the genetic strain.

Most values of serum biochemical constituents evaluated were statistically different between females and males, suggesting a different pattern for each gender.

Further studies are required to evaluate the blood biochemical profile of broiler breeders, considering gender and age.

\section{REFERENCES}

Alonso-Alvarez, C. Age-dependent changes in plasma biochemistry of yellow-legged gulls (Larus cachinnans). Comparative Biochemistry and Physiology Part A. Molecular \& Integrative Physiology Journal 2005;140(4): 512-518.

Andreasen JR, Andreasen CB, Sonn, AB, Robeson, DC. The effects of hemolysis on serum chemistry measurements in poultry. Avian Pathology 1996;25(3): 519-536.

Barbosa TS, Mori CK, Polonio LB, Ponsano EHG, Ciarlini, PC. Perfil bioquímico sérico de galinhas poedeiras na região de Araçatuba. Revista Semina: Ciências Agrárias 2011;32(4):1583-1588.

Batina PN, Lopes STA, Santurio JN, Souza C, Martins DB. Efeitos da adição de montmorilonita sódica na dieta sobre o perfil bioquímico de frangos de corte intoxicados com aflatoxina. Ciência Rural 2005;35(4):826831.
Benez SM. Aves: criação, clínica, teoria, prática: silvestres, ornamentais, avinhados. $4^{\text {a }}$ ed. Ribeirão Preto: Tecmedd; 2004. p.332

Cobb. SF parent rearing management record [cited 2013 Nov 15]. 2013. Available from: http://www.cobb-vantress.com/docs/default-source/ cobb-500-guides/cobb500sf-parent-rearing-laying-record---english(grams)25BF39AB3EABF46297DB2B50.pdf

Evans AJ, Bannister DW, Whitehead CC, Siller WG, Wight PA. Changes in plasma lipid and glucose levels during the onset of fatty liver and kidney syndrome in chicks. Research in Veterinary Science 1977;23:275-279.

Harr KE. Clinical chemistry of companion avian species: a review. Veterinary Clinical Pathology 2002;31(3):140-151.

Hochleithner M. Biochemistries In: Ritchie BW, Harrison GJ, Harrison LR. Avian medicine: principles and application. Lake Worth: Wingers Publishing; 1994. p. 223-227.

Kudair IM, Al-Hussary NAJ. Effect of vaccination on some biochemical parameters in broiler chickens. Iraqi Journal of Veterinary Sciences 2010;24(2):59-64

Melillo A. Applications of serum protein electrophoresis in exotic pet medicine. Veterinary Clinics of North America Exotic Animal Practice 2013;16(1):211-225

Musa HH, Chen GH, Cheng JH, Yousif GM. Relation between abdominal fat and serum cholesterol, triglycerides, and lipoprotein concentrations in chicken breeds. Turkish Journal of Veterinary e Animal Sciences 2007;31(6):375-379.

Osorio JH, Flores-Ochoa JD, Uribe-Velasquez, LF. Comparación del perfil lipídico en dos líneas de pollos de engorde. Revista Científica 2012;22(6):553-559.

Peebles ED, Burnham MR, Walzem RL, Branton RL, Gerard PD. Effects of fasting on serum lipids and lipoprotein profiles in the egg laying hen (Gallus domesticus). Comparative Biochemestry and Physiology 2004;138(3):305-311

Ross JG, Christie G, Halliday WG, Jones RM. Hematological and blood chemistry comparison values for clinical pathology in poultry. The Veterinary Record 1978;102(2):29-31

Schmidt EMS, Locatelli-Dittrich R, Santin E, Paulillo AC. Patologia clínica em aves de produção - uma ferramenta para monitorar a sanidade avícola - revisão. Archives of Veterinary Science 2007;12(3):9-20.

Silva EN. Probióticos e prebióticos na alimentação de aves. Anais da Conferência Apinco de Ciência e Tecnologia Avícolas; 2000; Campinas, São Paulo. Brasil: FACTA; 2000. p.242.

Vieira NS, Rosa AP, Zenella I, Maiorka A, Manera PR. Avaliação de diferentes programas de restrição alimentar na recria de matrizes avícolas tipo corte. Revista Ciência Rural 1995:25(3):455-460. 